\title{
Neolithisation in Polish Territories: Different Patterns, Different Perspectives, and Marek Zvelebil's Ideas
}

\author{
Marek Nowak $\mathrm{a}^{*}$ \\ ${ }^{a}$ Institute of Archaeology, Jagiellonian University, Golębia Street 11, 31-007 Kraków, Poland
}

\section{ARTICLE INFO}

\section{Article history:}

Received: 29. November 2012

Accepted: 21. May 2013

\section{Key words}

Neolithisation

Poland

Mesolithic

hunter-gatherers

Linear Pottery culture

Funnel Beaker culture

Marek Zvelebil's ideas

\begin{abstract}
$A B S T R A C T$
The neolithisation of Polish territories, approached from a global perspective, seems to proceed in both a complex and heterogeneous way. This was primarily caused by the highly transitional location. Additionally, the more or less fundamental differences in our understanding of the pivotal terms and phenomena play a major role in the insufficient and ambiguous state of knowledge on the discussed topic. Nevertheless, the fact that groups of classic foragers and foragers with selected elements of the Neolithic package existed simultaneously with farming communities is of the utmost importance. This paper examines possibilities for enriching the current state of knowledge with ideas on various aspects of neolithisation processes worked out by Marek Zvelebil. The opinion is put forward that Marek Zvelebil's work can still provide both theoretical foundations and practical inspiration for further research on neolithisation in East-Central Europe.
\end{abstract}

\section{Introduction}

From the ecological perspective, the territory of present day Poland has a highly transitional character. It covers fragments of the basic European landscape and environmental zones, such as the North European Plain, the East European Plain, Central European uplands, and Central European mountains. This is undoubtedly one of the reasons why the processes of neolithisation in this area were complex and heterogeneous (Figure 1). This situation has also been brought about by the more or less fundamental differences amongst Polish archaeologists in their understanding of the notions pivotal to the processes under consideration.

The first Neolithic communities appeared in the territory of Poland about the mid-sixth millennium BC. Their archaeological remains belong to the Linear Pottery culture (LBK), a grouping which spread from the Paris Basin to western Ukraine and from southern Transdanubia to certain areas of the North European Plain. In Poland, this grouping was recorded primarily in the fertile loess areas of Little

*Corresponding author. E-mail: mniauj@interia.pl
Poland and Silesia. It has also been found in the lowland zone. There, the largest concentrations of LBK sites were identified in Kuyavia and Chełmno Land, while smaller concentrations are also known from Great Poland, Western Pomerania, and Pomerelia. In the lowlands, as in the uplands, LBK groups initially settled the larger or smaller enclaves of fertile soils.

The LBK disappears from the Polish archaeological record at the beginning of the $5^{\text {th }}$ millennium $\mathrm{BC}$, as is also the case in other parts of Central Europe. In enclaves previously occupied by LBK populations, Neolithic groups developed which were, in general, descended from the "Linear" substratum. In the first half of the $5^{\text {th }}$ millennium BC they are archaeologically reflected by the Stroked Pottery culture in western Poland and the units described jointly as the Lengyel-Polgár complex (L-PC) in south-eastern Poland. The latter term emphasises the indisputable fact of the strong connections between these units and Late-Neolithic/Eneolithic cultural centres in the Carpathian Basin. After the mid-fifth millennium BC, western Poland was also included into the range of L-PC. This tradition continued locally up until the mid-fourth millennium BC. In essence, the groups in question still tended to use the most fertile and productive enclaves. 
The territories outside these enclaves were definitely not uninhabited. In the $6^{\text {th }}$ and $5^{\text {th }}$ millennia $\mathrm{BC}$, hunter-gatherer communities continued to live there, particularly in the lowland zone. They can be referred to as Late Mesolithic and Paraneolithic groups (Figures 1 and 2). The latter ones (i.e. the "Polish branches" of the Narva, Neman, and Ertebølle cultures) can be characterised as hunter-gatherers who possessed certain elements of the Neolithic package, not connected with agro-pastoral subsistence. Within the discussed period, they basically existed in the $5^{\text {th }}$ millennium BC.

It therefore seems that we are involved here with a subsistence (agriculture vs. hunting/gathering) and cultural (Neolithic vs. Late Mesolithic) dualism, enriched by transitional phenomena (Paraneolithic). The dualism of this kind began to change around $4000 \mathrm{BC}$ due to the appearance of the Funnel Beaker culture (TRB). Over the first half of the $4^{\text {th }}$ millennium BC, the TRB gradually encompassed Southern Scandinavia, the northern part of Central Europe from the Netherlands to the Polish lowlands, and-something which is at times neglected - considerable areas of the southern, upland part of Central Europe. Its "bearers" settled all the ecological zones and not only those which were the most favourable for farming. Roughly speaking, with this archaeological culture most of the territory of Poland came irreversibly within the orbit of the Neolithic. This is why the spread of the TRB may be referred to as the second stage of neolithisation (Figure 2) which finally proved to be even more important than the first one.

On the other hand, TRB populations surely did not encompass the entire territory under discussion. There still existed groups whose subsistence was based on hunting and gathering. As in the previous period, they frequently possessed, adopted, and adapted selected Neolithic elements, in the first place pottery. They consistently and firmly resisted, however, the adoption of farming and animal husbandry as basic sources of food. They should still be referred to as the Paraneolithic (Figure 2). Interestingly, abundant remains of groups of this kind have been discovered primarily in NorthEast Poland but also locally within the formal range of the TRB. Paraneolithic societies were incorporated into the agricultural formation only during the Late Neolithic (into the Globular Amphorae and Corded Ware cultures) and the Early Bronze Age (into the Trzciniec culture?), i.e. within the $3^{\text {rd }}$ millennium $\mathrm{BC}$ and the first half of the $2^{\text {nd }}$ millennium $B C$.

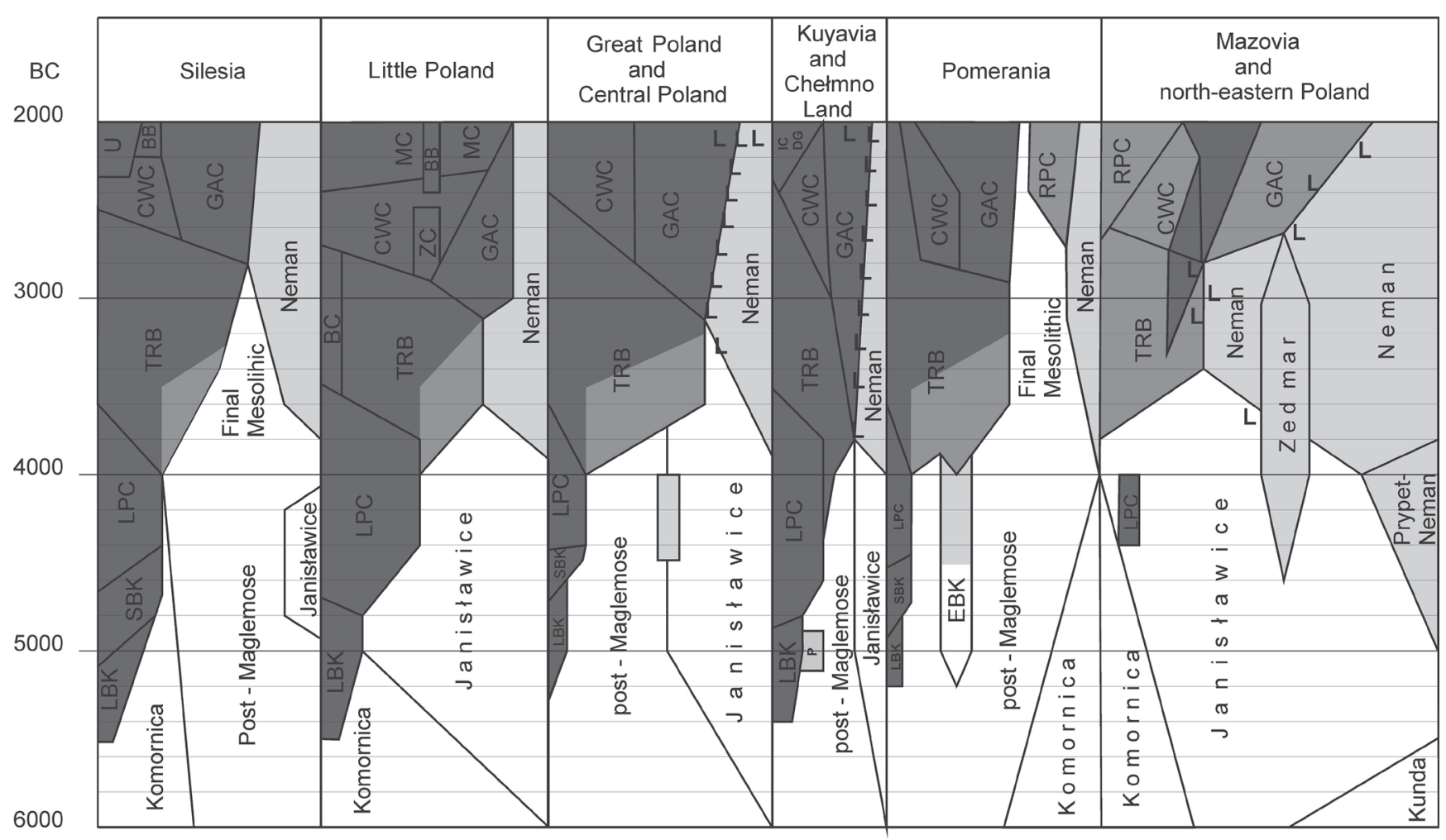

Figure 1. Archaeological cultures and the primary socio-economic formations in Polish territories between 6000 and 2000 BC. This vision of the Neolithic development was published in 2007 (Nowak 2007, fig. 7). The original version (with the original captions below) is shown here, to emphasize the complexity of the neolithisation processes in the Polish territories. This vision is characterized by an extremely optimistic approach to the "long chronology" of the Mesolithic communities. 1 - agro-pastoral and pastoral Neolithic, 2 - agro-pastoral Neolithic with the significant contribution of hunting and gathering, 3 - pottery-using hunter-gatherers (proto-Neolithic), 4 - hunter-gatherers (Mesolithic); LBK - Linear Pottery culture; SBK - Stroke Band Pottery culture; LPC - Lengyel-Polgár complex; TRB - Funnel Beaker culture; GAC - Globular Amphorae culture; CWC - Corded Ware culture; U - Únětice culture; BB - Bell Beakers; BC - Baden culture; ZC - Złota culture; MC - Mierzanowice culture; P - sites of Podgaj 32 type; IC - Iwno culture; DG - Dobre Group; $\mathrm{RPC}$ - Rzucewo/Pamariu culture; L - pottery of Linin type. 


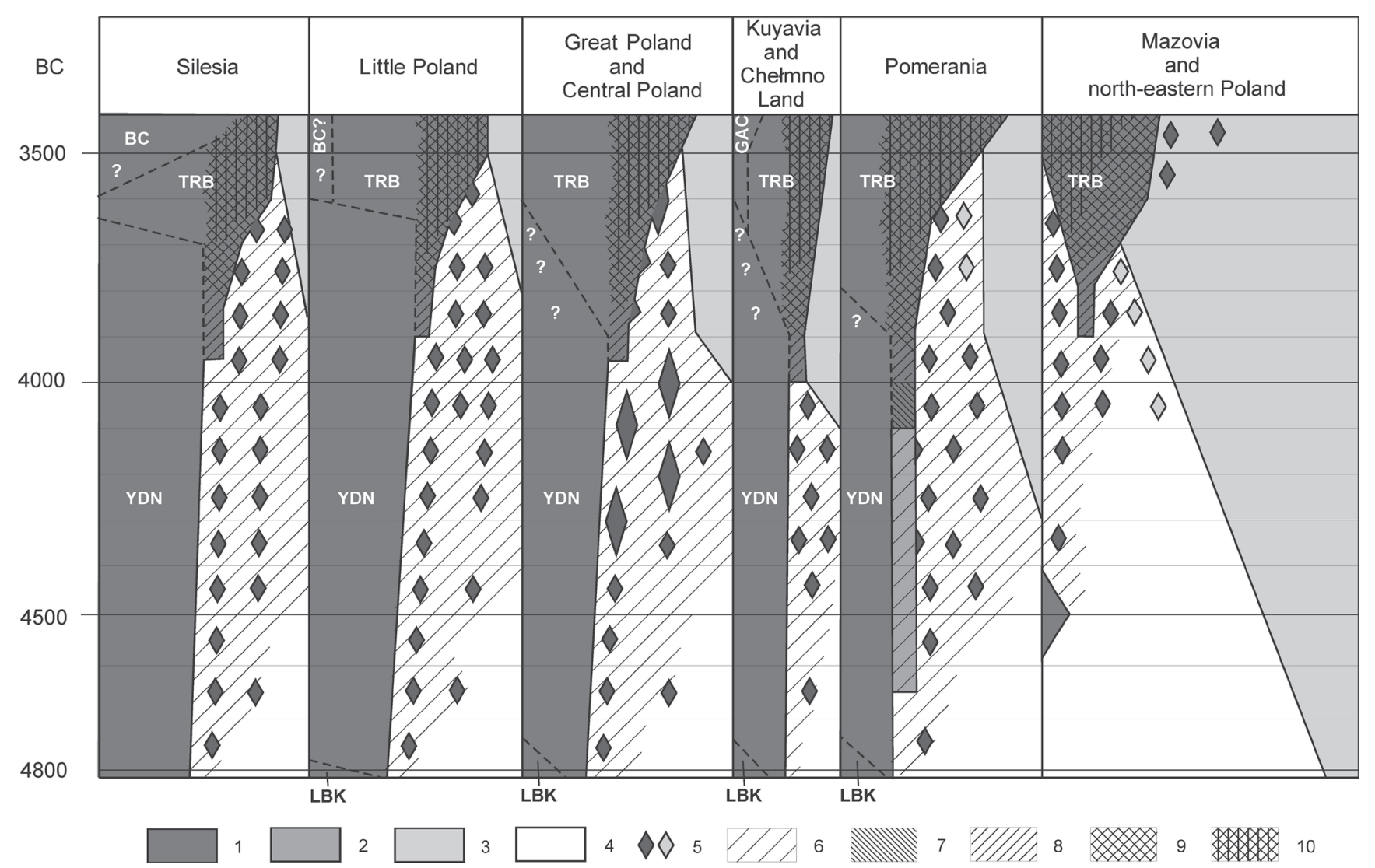

Figure 2. The second phase of neolithisation in Polish territories. This scheme, which is an attempt to explain the second phase of neolithisation, primarily associated with TRB, was published in 2009 (Nowak 2009, fig. 114). It is shown here with minor modifications (but with the original captions), again to emphasize the complexity of neolithisation in Polish territories. In comparison with Figure 1, the less optimistic version of the "long chronology" of the Mesolithic communities, a slightly different chronology of the early TRB, as well as the introduction of the term "Paraneolithic" should be noted. 1 - Neolithic; 2 - proto-Neolithic; 3 - Paraneolithic; 4 - Late Mesolithic; 5 -penetrations of Neolithic and Paraneolithic populations outside the areas of their dense settlement; 6 - the pre-formative stage of the second phase of Neolithisation; 7 - the initial formative stage of the second phase of Neolithisation; 8 - the secondary formative stage of the second phase of Neolithisation; 9 - the expansion stage of the second phase of Neolithisation; 10 - the saturation stage of the second phase of Neolithisation; LBK - Linear Pottery culture; YDN - younger "Danubian" Neolithic (Stroke Band Pottery culture and LengyelPolgár complex); TRB - Funnel Beaker culture; BC - Baden culture; GAC - Globular Amphorae culture.

These processes should perhaps be described as the third stage of neolithisation.

\section{The significance of Marek Zvelebil's ideas for the debate on the neolithisation}

The rise and spread of the Neolithic in the territory of Poland, presented above in a general outline, is still insufficiently investigated, both from the factual and interpretative points of view. In light of this situation, perhaps a clarification of these problems might be found in the works of Marek Zvelebil. In my opinion, particular attention should be paid to certain issues consistently raised in his publications.

Firstly, one of Marek Zvelebil's indisputable contributions is re-emphasising the position of Holocene hunter-gatherers in the general schemes of the cultural development of human societies, including the archaeological perspective (Zvelebil 1986a; 1986b; 1989; 1996a; 2001; 2003a; 2003c; 2006). Zvelebil's works were of course only part of a broader trend in research, noticeable in anthropology and ethnography (to a lesser extent in archaeology) since the late 1960s, which resulted in a kind of "rehabilitation" of ethnographic and archaeological hunting-gathering communities (e.g. Price, Brown 1985). The works of $M$. Zvelebil convincingly demonstrate how complex and multi-dimensional they were (O'Shea, Zvelebil 1984; Van Gijn, Zvelebil 1997; Zvelebil 1997; 2003a; 2003c, 185-190; Zvelebil, Jordan 1999). An application of the observations obtained from "ethnographic" groups of hunter-gatherers to their prehistoric (primarily Mesolithic) forebears is particularly important (Zvelebil 1996b, 331-333; 2003a, 17). A thesis can thus be formulated concerning the cultural uniformity of prehistoric and historic hunter-gatherers (Zvelebil 2003a; 2006, 185). Several studies (Zvelebil 1981; 1994; 1995a; 2003b) demonstrate that Mesolithic groups were capable of efficient and flexible adaptation to a particular type of environment. They functioned this way for a relatively long time, also in confrontation with the Neolithic (Zvelebil 1981; 2004a, 52; 2006).

Secondly, in a number of his works Marek Zvelebil addresses the issue of understanding such notions as the 
Neolithic and neolithisation in modern archaeology. The position he consistently takes is that the most important and basic marker is agro-pastoral subsistence (Zvelebil 2004a, 43; Zvelebil, Lillie 2000, 59; Zvelebil 1996b; Zvelebil, Dolukhanov 1991). He firmly refutes other definitions, such as those based on post-processual concepts of the new Neolithic mentality (e.g. Thomas 1999, 7-17). The transition to agro-pastoral subsistence should consequently be regarded as the only factor which is sufficiently universal and precisely defined to avoid an ambiguity in approaching the Neolithic and neolithisation (Zvelebil, Lillie 2000, 59-60). What is more, the papers of M. Zvelebil suggest that the term "Neolithic" should be reserved for such situations when the food acquired from farming and animal husbandry becomes predominant (Zvelebil 1996b, 325; 1998, 11).

This leads us to the third aspect of Marek Zvelebil's thinking concerning the processes of neolithisation. Together with P. Rowley-Conwy, he developed a comprehensive model of such processes known as the "availability model" (Zvelebil, Rowley-Conwy 1984; 1986). The model was initially developed for the littoral societies of Western and Northern Europe, but attempts were consequently made to extend it to other parts of Europe, including the territory of Poland (Zvelebil 1996b; 1998; 2001; 2004a; 2005, 90-91; Zvelebil, Lillie 2000). Controversial in many details as it was, the model was the first attempt to present the process of local neolithisation as a result of various forms of complex and long-lasting contacts between those groups which had already turned Neolithic and those prior to neolithisation. Initially, these contacts were supportive for both the hunting-gathering and farming communities (Zvelebil 2004a, 49) (Figure 3: A), only for the situation to change to the foragers' disadvantage (Figure 3: B). M. Zvelebil suggests that the disruptive effects appeared as a result of the commercialisation of their economic system (Zvelebil $2004 a, 49-50 ; 2006,187)$. This supposedly led to the disintegration of their cultural system and to accelerated neolithisation. The model of the contacts between foragers and farmers draws extensively on a set of concepts developed in theoretical discussion on agricultural frontiers and frontier mobility (Dennel 1985; Zvelebil 1996b; 1998; 2001). The "availability model" assumes the existence of a number of transitory stages between the extreme forms, i.e. between the pure Neolithic (farmers) and the pure Mesolithic (foragers).

Fourthly, a number of works by Marek Zvelebil focus on the genesis of archaeological units associated with the neolithisation of East-Central and Eastern Europe, the Baltic Sea basin in particular (Zvelebil 1996b; 1998). In the context of Polish territories, the discussion on the origins of the LBK and TRB is of particular importance.

Even in the discussion of the genesis of LBK, the role of the local Mesolithic context has been repeatedly emphasised. Originally, he proposed that the formation of the LBK itself, in its core area (i.e. in Lower Austria, northern Transdanubia, south-western Slovakia and southern Moravia), took place primarily within indigenous Late Mesolithic populations, as a result of contacts with the Neolithic groups from the northern peripheries of the Starčevo-Körös-Criş complex (Zvelebil 2001, 6). In further publications, M. Zvelebil placed a greater emphasis on the role of the Starčevo-KörösCriş complex in the crystallisation of LBK. The formation of LKB is expressed as "[...] selective integration of ancestral traditions - both indigenous Mesolithic and Starcevo/Körös Neolithic - into a new cultural tradition by the means of routine practice and social agency" (Zvelebil 2004b, 199). He even accepts "[...] limited immigration from StarčevoKörös farming communities [...] within the structural framework of the agricultural frontier relationships $[\ldots]$ " (Zvelebil 2004a, 48). These processes led to the development of such cultural attributes which enabled later expansion.

The spread of the LBK from this area followed the pattern of leapfrog colonisation rather than demic diffusion. As a result, fertile niches of Central Europe were settled, and contacts/frontier mobility between LBK foragers-turnedfarmers and indigenous foragers were established. This was of crucial importance for further neolithisation of the area (Zvelebil 2004b: 199).

In principle, M. Zvelebil accepted the connection between the first European Neolithic in the Balkans and LBK with allochtonic languages and (pre-) Indo-European populations (which, in fact, is an inconsistency, if indigenous Mesolithic groups participated in the crystallisation of LBK). The further spread and evolution of Indo-European languages in Europe was to take the form of a "contact-induced language shift" followed by the process of creolisation (Zvelebil 1995b). In other words, this spread was due to a mixture of the immigrant and indigenous populations, where foreign elements were adopted (but at the same time transformed) by the locals because of, among others, prestige reasons. It is proposed that the Indo-European language spoken by the LBK populations ("Old European") would have gained the status of a commonly accepted lingua franca, within the situation of the developed network of contacts and frontier mobility (Zvelebil 2002, 386-388).

Worthy of note is that in other works this idea was extended to matters other than linguistics. A "cultural creolisation" which would include all of the basic elements of a cultural system was proposed (Zvelebil 2001; 2005). In a way, this is an extension of the "availability model", with its ideas on the destructive impact of Neolithic patterns, in the long run, on the established hunter-gatherer culture.

The formation of TRB would be the further result of the processes described above, occurring at various paces and scales, between the already neolithicised societies representing LBK/Danubian traditions and indigenous hunting-gathering societies (Zvelebil 1995b, 192; 1996b, 339-340; 1998, 21-22; 2001, 9-10; 2005). Consequently, the early TRB (till ca. $3600 \mathrm{BC}$ ) is viewed as a "substitution phase" (Zvelebil 2004a, 50-52). M. Zvelebil does not precisely state, however, where TRB appeared for the first time; he generally mentions northern Germany and Poland (Zvelebil 2004a, 50, 55; 2005) as well as Denmark and southern Sweden (Zvelebil 2006, 179). 

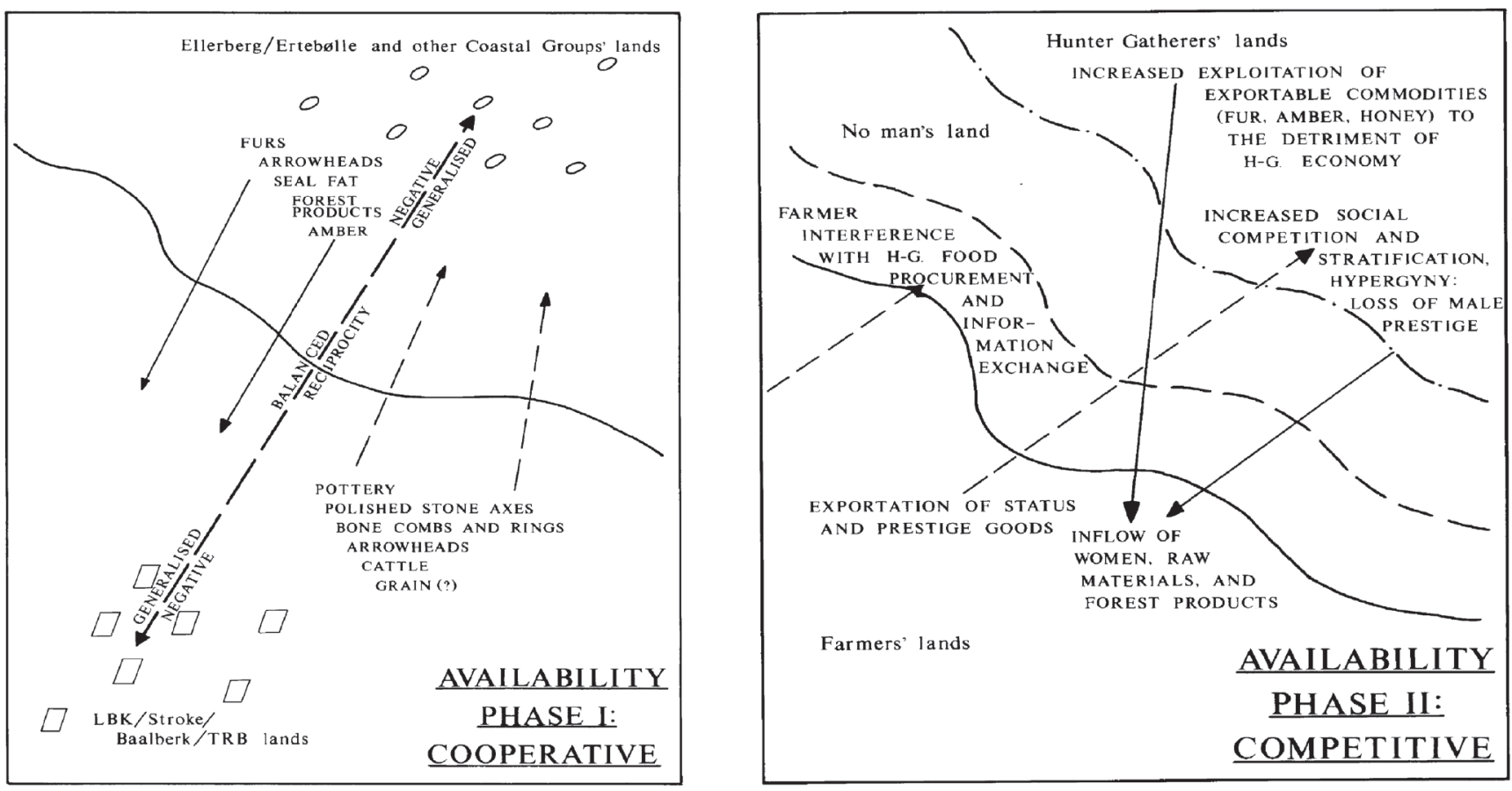

A

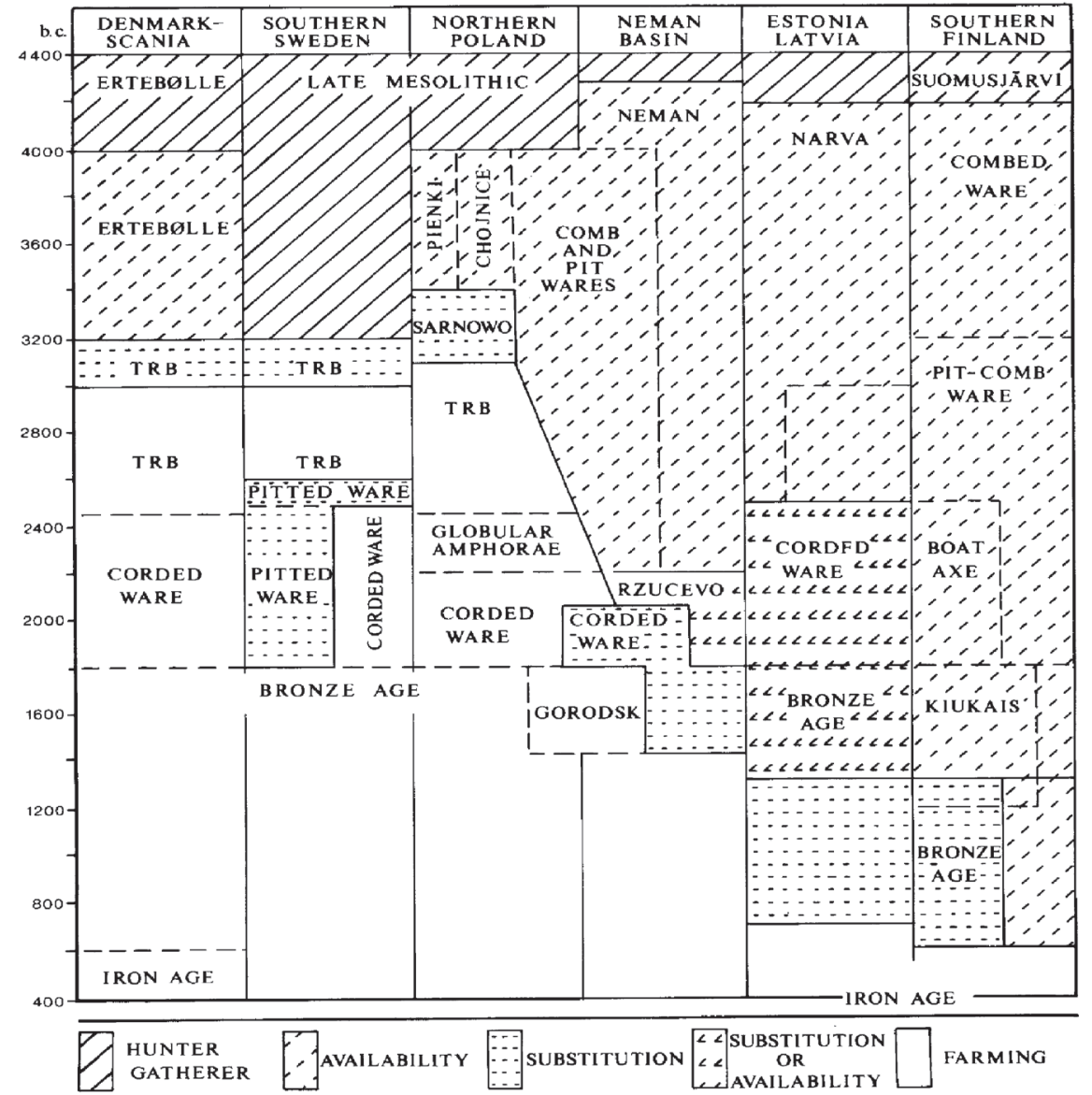

C

Figure 3. Graphic schemes related to the "availability model". A, B - the two basic stages of the "availability phase" discerned by M. Zvelebil (1998, figs 1.5, 1.8), $\mathrm{C}$ - "transition to farming along the southern rim of the Baltic in terms of the availability model" (Zvelebil 1998, fig. 1.4). 


\section{The potential role of Marek Zvelebil's ideas in the discussion on the neolithisation of Polish territories}

\subsection{The genesis of the LBK}

The origins of the first Neolithic archaeological culture in the Vistula and Oder basins have never provoked much doubt in Polish archaeological literature. The LBK was commonly regarded as reflecting the populations that came from the middle Danube basin, about the mid-sixth millennium BC, and which colonised over a relatively short time the alreadymentioned enclaves characterised by favourable ecological conditions (Kulczycka-Leciejewiczowa 2000; 2010). The same scenario applies to other territories within the LBK range, as well (e.g. Bogucki 2003; Gronenborn 2007, 77, 79). Different views certainly appear within European literature which assume either partially (e.g. Gronenborn $1999)$ or fully local genesis of the discussed culture (e.g. Mateiciucová 2008). On the Polish ground they have found neither approval nor any particular reflection.

A similar conformity with M. Zvelebil's concepts may be observed in the understanding of the Neolithic. The appearance of the first archaeological groupings with direct and numerous evidence for agriculture and animal breeding is taken as the hallmark of its onset. This approach, however, entails that the emergence and spread of the LBK by no means defines the beginning of the Neolithic for the majority of the Polish territories. Roughly $70 \%$ of these territories remained beyond the extent of this cultural formation. In other words, the textbook date of $5500 \mathrm{BC}$ for the start of the Neolithic is a far-reaching simplification.

Marek Zvelebil's works may undoubtedly contribute to a better recognition of another problem connected with the LBK in Poland, which is seldom addressed. Traditional reflections on this archaeological culture, including the issues of its origin and spread, are biased. The quite obvious fact that the LBK expansion did not fully eliminate earlier demographic (and language?) stratum (see Figures 1 and 2) has been passed over. The maps, where concentrations of the LBK sites or the LBK range are surrounded by empty areas are a good example of this (e.g. Czekaj-Zastawny 2008, fig. 53; Kulczycka-Leciejewiczowa 2000, fig. 3). The impression appears as if the LBK operates in a kind of population and cultural vacuum.

In past reality the LBK people lived within the context of the hunter-gatherer word or world. This fact follows not only from settlement geography and chronological reasons (Nowak 2007; 2009, 211-248), but also from more recent genetic data (Bramanti et al. 2009). In such a case a number of interesting issues appear. First and foremost, this is the issue of the relations between "immigrant" Early Neolithic farmers and "indigenous" hunter-gatherers. Did these relationships exist at all, or did the two communities remain completely separated? If such relationships took place, what was their intensity, what was their everyday practice and what was their impact on both cultural systems. Particularly important is the question if hunter-gatherer communities had been taking over the Neolithic attributes and behaviour, transforming themselves into a "Linear" farming communities and possibly - taking part in the spread of the LBK through colonization. In turn, the absence of relations of this kind also raises questions about the reasons for this state of affairs.

In such circumstances, theoretical constructs such as "frontier mobility" or the "availability model" may be used as a starting point for a detailed description of potential interactions, even if these models may seem excessively theoretical and based on ethnographic data and not necessarily corresponding with archaeological data.

These models strongly suggest that different kinds of relationships between communities of even extremely different cultural systems are inevitable and quite obvious. In the discussed case, however, one faces a rather surprising situation. Namely, the archaeological evidence for LBK Mesolithic/Paraneolithic interactions in Polish territories remains rather modest, particularly in contrast to the large number of LBK and Mesolithic/Paraneolithic sites and despite their spatial proximity in certain regions (e.g. Domańska 2003) and visible traces of penetrating of the outskirts of the "old-agricultural" enclaves by LBK groups (e.g. Czerniak 1994: 54-58).

Certainly, the lack of evident Mesolithic features in LBK flint inventories ${ }^{1}$ is the most important observation (see e.g. Balcer 1986: 102-105, 112-1132). This also applies to scarce LBK sites situated outside "old-agricultural" enclaves, in the zones typical of hunter-gatherer settlements, e.g. in Pomerelia (Felczak 2005). It is also difficult to detect "Linear" characteristics in Late Mesolithic/Paraneolithic chipped lithics.

The chocolate flint in the LBK and obsidian in the Late Mesolithic are frequently quoted as results of interactions between these cultural systems (Balcer 1986, 113; Kozłowski $1989,157)$. It is quite possible to imagine, however, that the distribution of these raw materials was carried out without the participation of those interactions.

It is a known fact that single pollen indicators of agriculture have been sporadically recorded in the European Mesolithic contexts (see Behre 2007; Gehlen 2006). Such signals (Cerealia, Plantago lanceolata) are also occasionally reported in Poland (Pelisiak et al. 2006, 15-19, fig. 4). They raise a number of doubts, however. Recently, K.-E. Behre has extremely convincingly pointed out that there is reasonable distrust as to the ability to precisely distinguish pollen grains of cereals and local wild grasses (Behre 2007, 204-206). Moreover, these indicators may be the remains of Neolithic penetrations which left no archaeological traces. Finally, the spread of agriculture indicators may result from wind transport (see Ralska-Jasiewiczowa, Van Geel 1998, 271).

\footnotetext{
${ }^{1}$ The author sees the issue of similarities between Mesolithic and Neolithic flint industries differently than e.g. I. Mateiciucová (2008). This matter would require a separate, extensive discussion.

${ }^{2}$ Although the intention of the cited paper was to actually demonstrate the presence of "archaic" (Mesolithic) elements in Neolithic flint industries related to the neolithisation, it finally demonstrates that in the case of the LBK these elements are extremely scarce and controversial.
} 
Even if one accepts, however, the presence of domesticates in a non-Neolithic context, neither the development of the Neolithic independent of the LBK nor a significant increase in the LBK range can be observed outside the "oldagricultural" enclaves.

The only Neolithic component which may actually be found within the "Mesolithic oikumene", but not the other way round, are the polished stone tools of the Schuhleistenkeile type. They are found throughout the entire Central European lowlands (Ilkiewicz 2005; Terberger 2006, 139-140; Zvelebil 1998, 48). This could obviously be a clear indication of one-sided Mesolithic-Neolithic relations. However, not all stray finds of this kind have to have been derived from the Mesolithic context. One can easily envisage that they are the remains of penetrations of "hunter-gatherer" zones carried out by certain LBK groups.

Altogether, it should be assumed that the interactions expected in the "availability phase I" (Figure 3: A) were relatively weak and not reciprocal. There is probably no other way of explaining it, but to assume fundamental cultural differences between farming and foraging communities. These differences were so radical that they resulted in the existence of a clear, non-permeable, mental barrier. It should be added that characteristics of the LBK such as: a "lowspatial" pattern of settlement and economy (Bogaard 2004; Grygiel 2004, 614-617, fig. 470), almost exclusive reliance on domesticated food (Nowak 2009, 62-64) and a low population density (e.g. Zimmermann et al. 2004) could have contributed to and perpetuated this situation. The spatial needs of the LBK groups were insignificant, and, more importantly, limited to one (small) ecological zone. Selfsufficient groups of farmers occupying exclusively limited, microregional (up to several square $\mathrm{km}$ ) and mesoregional (up to several hundred square $\mathrm{km}$ ) areas (Grygiel 2004), did not cause any particular complications for the life of huntergatherer communities. It is distinctive that even in areas inhabited by LBK people their environmental impact was negligible, as testified by pollen profiles (e.g. Bogucki et al. 2012; Godłowska et al. 1987).

In the light of recent research, one can speak about more intensive contacts only in the $5^{\text {th }}$ millennium $\mathrm{BC}$, during the development of the post-Linear Neolithic. These contacts still seem to be a one-sided process, however, which means certain elements of the Neolithic material culture being recorded in the Mesolithic/Paraneolithic context. Findings of Neolithic pottery should be primarily indicated (CzekajZastawny et al. 2011a; 2011b; Gumiński 2011) as well as, similarly to the previous period, single finds of domesticates (Gumiński 1998, 106-107; 2003) and polished stone tools within the "hunter-gatherer oikumene". There is no evidence for the disruptive impact of such relationships either on Mesolithic/Paraneolithic or on Neolithic societies contrary to M. Zvelebil's ideas (Zvelebil 1998, 19-21; 2004a, 52). In this case, however, one can suggest the occurrence of phenomena such as a "contact-induced language shift" or/ and "creolisation" to describe the impact of the Neolithic communities on Mesolithic/Paraneolithic ones. This could be due to the slightly larger range of the L-PC settlement, more confident and longer entering the "hunter-gatherer" zone (Czerniak, Pyzel 2011) and even to locally more intense transformations of the environment (Bogucki et al. 2012; Godłowska et al. 1987). Concurrently, it should be emphasized that in the $5^{\text {th }}$ millennium $\mathrm{BC}$ a major part of the territory under discussion was still outside the direct influence of the Neolithic (understood as basically a farming phenomenon).

\subsection{The late hunter-gatherers}

Another extremely important issue concerns the late hunter-gatherer societies which lived in the territory under discussion. There are many aspects to this issue. How long did these societies function? How large were they? What was their cultural system? Finally, what was their role in the neolithisation?

Generally speaking, the Polish literature presents a considerable range of views on this topic. As concerns the chronology, the data collected over the last 20 years for the hunter-gatherer contexts actually (and surprisingly!) cover the entire Neolithic period (Nowak 2001; 2007; 2009) (see Figures 1 and 2). Importantly, they are not exclusively from Paraneolithic contexts. It may follow from this that forager societies in many variants existed throughout the entire Neolithic period. This does not correspond with the traditional views (Kukawka 1997; Schild 1998). Their supporters rightly emphasise problems of the homogeneity of Mesolithic/Paraneolithic sites which are usually located on dunes, peats or sands. Thus, it is not certain whether the radiometric dates obtained, or the pottery fragments discovered should in fact be connected with Mesolithic/ Paraneolithic flint inventories. In contrast, the traditional approach does not explain what happened to Mesolithic populations after the mid- $6^{\text {th }}$ millennium $\mathrm{BC}$. We are consequently dealing with a distinct dichotomy of opinions which influences additional issues. Supporters of a short chronology for hunter-gatherer societies, for example, reject their involvement in the neolitisation (e.g. Kukawka 1997), while those who favour a long chronology of course accept it (e.g. Kozłowski 1989).

Marek Zvelebil's theoretical constructions and ethnoarchaeological studies obviously promote the views which assume the long functioning of these societies and their multi-dimensional, autonomous transformations. Relying on these ideas, I am of the opinion that hunter-gatherer communities in the $6^{\text {th }}, 5^{\text {th }}, 4^{\text {th }}$, and $3^{\text {rd }}$ millennia BC evolved independently in relation to parallel Neolithic communities, and did not passively wait for the "Neolithic Godot" as one might expect due to many popular opinions. In other words, within these communities a number of specific processes took place, which proceeded quite independently of the Neolithic. Instances which could be mentioned include: the progressive unification of flint tools (Nowak 2009, 80-81, $250,255)$, the growing intentional impact on the environment (Nowak 2001; 2009, 71, 77, 254-255) or the increase in the importance of plants and smaller animals (Galiński 
2002, 311; Kubiak-Martens 1999; 2002; Makowiecki 2003, 54-72).

Certainly, the fact that the territory of Poland since the $5^{\text {th }}$ millennium BC produced abundant evidence for huntinggathering groups with Neolithic and Neolithic-like elements (pottery, single traces of domesticated plants and animals, Neolithic-type flint artefacts) is the most important from the discussed perspective. As is already known, these groups can be denominated as Paraneolithic (Figure 2) (in light of M. Zvelebil's definition of the Neolithic, this phenomenon should not be included, however, into the Neolithic proper). The majority of the foregoing elements do not come from the local Neolithic (Czerniak, Pyzel 2011; Józwiak 2003; Józwiak, Domaradzka 2011; Kabaciński, Terberger 2009). They originate from Eastern Europe and Southern Scandinavia. A major research issue is the origin of this phenomenon in Polish territories. It is traditionally discussed in terms of migratory movements (Józwiak 2003). In the author's opinion, however, transformations of the local Mesolithic should also be considered. This would mean that Mesolithic communities, particularly in NorthEastern and Central Poland, in the $5^{\text {th }}, 4^{\text {th }}$, and $3^{\text {rd }}$ millennia $\mathrm{BC}$, introduced the aforesaid elements into their system of information flow primarily from the East and North-East, from the so-called Forest Neolithic cultures.

In the $4^{\text {th }}$ and $3^{\text {rd }}$ millennia $\mathrm{BC}$, the relationships between the above cultural complex and Neolithic become closer and more intensive (Figure 1), which is manifested in the so-called Linin type pottery, combining Paraneolithic and
Neolithic attributes (Józwiak 2003; Kempisty 1983). This pottery is widespread throughout the entire territory of Poland, but is particularly typical of its east-central and north-eastern parts.

It should be assumed that in the case of the Paraneolithic a situation similar to the "availability I" model (cooperative - Figure 3: A) occurred, operating on the principle of stationary frontiers. These relationships were essentially beneficial for the Paraneolitic people. In effect, a cultural pattern was generated, which was an alternative to the Neolithic, but also to the typical Mesolithic. This pattern was based on Mesolithic, hunting-gathering traditions and on some Neolithic traditions, and meant a perfect adaptation to the local environment. From the subsistence and social point of view there were no reasons for turning into the Neolithic. What is more, contacts with a foreign cultural system and even an awareness of its existence could trigger new (counter-) behaviours, strengthening their own cultural system. Hence, the eastern and north-eastern patterns of mentally close communities were gladly accepted and adapted.

\subsection{The genesis of the TRB}

Another key problem of the Polish (and Central European) Neolithic is the genesis of the TRB. As has already been mentioned, these processes may generally be called the second stage of the neolithisation (Figure 2). Two alternative groups of explanations are present in the Polish literature. The first is based on early dates from Kuyavia and Chełmno
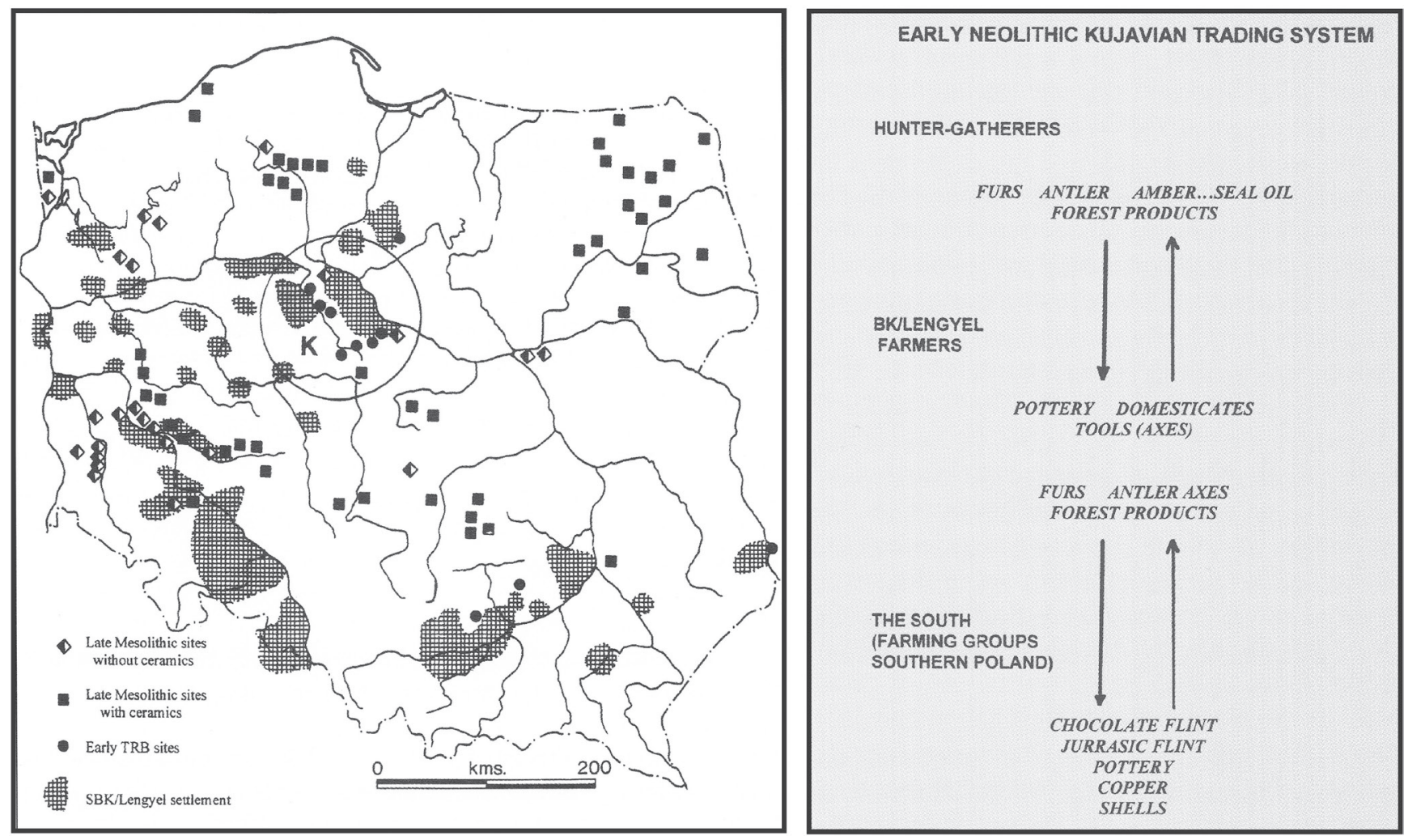

Figure 4. The spatial relations of Neolithic and non-Neolithic groups and the exchange system during the post-LBK Neolithic, according to M. Zvelebil (2005, figs 1,3); the original captions were left. The depicted ideas refer basically to the dawn of the second stage of neolithisation. 
Land and suggests that the TRB was formed just in (one of?) these areas, primarily on the basis of local L-PC societies (Czerniak et al. 1991; Kośko 1981; Kukawka 1997; 2010); whether hunter-gatherers were involved in this process remains unclear. The second explanation links the source of the processes in question with hunter-gatherer groups (Jankowska, Wiślański 1991; Nowak 2009).

Interestingly enough, M. Zvelebil has pointed out both basic possibilities. On the one hand, he anticipated that the TRB genesis should be linked with a west-Baltic centre, primarily because of the presence of "complex" huntergatherers in that area (Zvelebil 2004a, 50, 55). On the other hand, he also postulated the existence of additional, independent centres of the TRB formation, e.g. in Kuyavia (Zvelebil 2005) (Figure 4). Currently, with the early TRB dates from that region being more and more commonly rebutted (Nowak 2009, 263-282; Rybicka 2011), such a claim is less likely now than it seemed even only a few years ago.

More importantly, however, theoretical schemes such as the "availability model", "frontier mobility" and "cultural creolisation" very strongly suggest that the formation of TRB ensued from intensive and relatively rapid interactions between Late Mesolithic and Neolithic communities. These interactions influenced all chunks of the former cultural system, leading to the emergence of the (already!) Neolithic system.

Relevant archaeological data made possible the formulation of a thesis that the crystallisation of the TRB according to this scenario took place in the south-western Baltic zone, at about the end of the $5^{\text {th }}$ millennium BC. This zone encompassed the littoral areas from Holstein to Central Pomerania (Hartz, Lübke 2005; Kabaciński, Terberger 2009). The formation of the TRB took place on the basis of late ("complex"?) hunter-gatherers (mainly the Ertebølle complex). Contacts and interactions with the Neolithic in this zone in the $5^{\text {th }}$ millennium BC are well attested to (see Klassen 2004). In Poland they are extremely clearly demonstrated at the Dąbki site (Czekaj-Zastawny et al. 2011a). These processes can be again qualified through reference to the "availability I" model (Figure 3: A). The author shares M. Zvelebil's view that "other forms of exchange, including information, partners, prestige items and raw materials may have played a role equal to or greater than food exchange" (Zvelebil 1998, 16). During the $42^{\text {nd }}$ and $41^{\text {st }}$ centuries BC (e.g. Hartz, Lübke 2005) a new economic, social, and ideological reality took shape ("initial formative stage"), which can be referred to as the "Early Beaker" one.

Data from the eastern part of Central Europe indicate that this new cultural model included a settlement pattern varied in terms of home size, microroregion size or the level of settlement stability. The pattern enabled flexible adaptations to different environmental, but also social and cultural conditions (Nowak 2009, 351-390). From the very beginning subsistence was based on "domesticated" food, while there are local hints of larger shares of "wild" food. Significantly, they are not limited to the early phase. This also suggests subsistence flexibility. Similar conclusions can also be drawn from the varied degree of anthropogenic impact visible in environmental data (Nowak 2009, 449$450,544-545$, and further references). There are signals of intense interference in the environment, but also of a moderate interference, "soft" interference and, interestingly, there are no human indicators, even in areas apparently inhabited by groups of the TRB. All types of these indicators cover all the developmental stages of the TRB. In addition, their greater territorial scope differentiates the TRB from the LBK and L-PC.

The initial emergence of the early-TRB model in Polish territories (apart from the central and western Pomeranian coastal zone) was a consequence of leapfrog colonization and ecological infiltration (see Zvelebil 2001, 2; Zvelebil, Lillie 2000, 62-63), as approaching from the north-west, in about 4000 BC. Attributes of this model were propagated, however, among local hunter-gatherer groups as a result of contact and frontier mobility, and perhaps as a result of certain processes such as elite dominance, gradually gaining common approval among a portion of them ("secondary formative stage").

Processes of this type were facilitated by long-lasting co-existence between farmers and hunter-gatherers in the Vistula and Oder basins. An intense flow of information between enclaves settled by LBK and particularly L-PC communities must have resulted in the passive involvement of numerous hunter-gatherer groups into these systems of information flow. Although the contacts between them were limited (hostile?), it caused an infiltration of general ideas and meanings characteristic of the Neolithic and the related practical knowledge. In short, in the $5^{\text {th }}$ millennium $\mathrm{BC}$ a mentality was formed which was ready to accept Neolithic attributes ("pre-formative stage"). A reluctance for direct copying of the patterns typical of the local Neolithic remained, however. In such a situation, the appearance of alternative Neolithic patterns, which could be quite freely instantiated and, what is not irrelevant, was introduced by the "Early Beaker" people of a close mentality and culture resulted in their rapid acceptance, the more so because these patterns provide an opportunity to symbolically enrich many forms of behaviour.

Due to its flexibility, the "Early Beaker" system became attractive to foraging communities, but also to farming communities. Therefore, its further expansion, after 3900 $3700 \mathrm{BC}$ (the exact date depends on the region), had a dual, migratory and cultural character and took place on the basis of both Mesolithic and Neolithic groups ("expansion stage"). This could be facilitated through natural openings of forests which took place in the $4^{\text {th }}$ millennium BC (elm decline and other connected transformations of the forest cover - RalskaJasiewiczowa 2004; Zachowicz et al. 2004).

From ca. 3750-3650 BC, perhaps as a result of demographic growth, a distinct increase in the number of TRB sites is clearly visible ("saturation stage"). The emergence of monumental sepulchral structures as symbolic markers of social stability, which possibly also legitimized 
the rights to a particular area, reflects these changes. Another determinant of this phenomenon was the development of larger settlements, with more stable household structures.

The proposed scenario assumes that the identification of the early TRB in Poland as the "substitution phase" in the "availability model" (Figure 3: C) should be rejected. Perhaps such a classification is valid for southern Scandinavia, but in Poland even the earliest sites of this culture reveal evident and numerous traces of farming and animal husbandry (Nowak 2009, 391-422).

\section{Conclusion}

In the territory of Poland, neolithisation was a multi-threaded and metachronous process. Neolithisation in its classic form can be observed here, i.e. the rapid appearance of groups with a complete "Neolithic package" (LBK), although there is also evidence for the presence of only selected elements of this package (Paraneolithic). There is an external, imposed neolithisation (LBK), and a more local one, triggered by local cultural transformations (TRB). Finally, along with the Neolithic, there is the long survival of forager groups. This situation is specific and unique on a European scale, because the various patterns of neolithisation, typical for different territories and cultural situations, take place in direct vicinity and with their confrontation capable of observation. All these factors are still given little emphasis, however, in the works of Polish archaeologists. The predominant approach is to focus on selected issues, with almost no attempt at a more comprehensive approach. The description of the various models of neolithisation as mutually correlated and (perhaps) dependent would be of particular interest, not only within the context of the territory of Poland. Marek Zvelebil's works provide the theoretical foundations for such a postulate, indicating the lines of research and methods of its falsification. In spite of Marek's untimely death, his works still provide us with enormous potential to exploit.

\section{Acknowledgement}

This paper is devoted to a memory of Marek Zvelebil (Marek - many thanks indeed). I would like to thank to Jaromír Beneš for his kind invitation and encouragement to write a contribution of this kind as well as for his incredible patience and understanding. As regards the patience and understanding I would also extend my gratitude to Ondřej Mlejnek and other members of the Editorial Board. I am deeply indebted to the two anonymous reviewers for providing constructive comments, criticisms, and suggestions.

\section{References}

BALCER, B. 1986: Zagadnienie neolityzacji ziem Polski w świetle badań przemysłów krzemiennych związanych z kulturami "ceramicznymi”.
Archeologia Polski 31, 95-124.

BEHRE, K.-E. 2007: Evidence for Mesolithic agriculture in and around Central Europe? Vegetation History and Archaeobotany 16, 203-219.

BOGAARD, A. 2004. Neolithic Farming in Central Europe. An Archaeobotanical Study of Crop Husbandry Practices. Routledge, London-New York.

BOGUCKI, P. 2003: Neolithic dispersals in riverine interior Central Europe. In: Ammerman, A., J., Biagi, P. (Eds.): The Widening Harvest: The Neolithic Transition in Europe. Looking Back, Looking Forward. Archaeological Institute of America, Boston, 249-272.

BOGUCKI, P., NALEPKA, D., GRYGIEL, R., NOWACZYK, B. 2012: Multiproxy environmental archaeology of Neolithic settlements at Osłonki, Poland, 5500-4000 BC. Environmental Archaeology 17, 45-65.

BRAMANTI, B., THOMAS, M. G., HAAK, W., UNTERLAENDER, M., JORES, P. TAMBETS, K., ANTANAITIS-JACOBS, I., HAIDLE, M. N., JANKAUSKAS, R., KIND, C-J., LUETH, F., TERBERGER, T., HILLER, J, MATSUMURA, S., FORSTER, P., BURGER, J. 2009: Genetic discontinuity between local hunter-gatherers and central Europe's first farmers. Science 326, 137-140.

CZEKAJ-ZASTAWNY,A. 2008: Osadnictwo społeczności kultury ceramiki wstęgowej rytej w dorzeczu górnej Wisty. Instytut Archeologii i Etnologii PAN, Kraków.

CZEKAJ-ZASTAWNY, A., KABACIŃSKI, J., TERBERGER, T. 2011a: Long distance exchange in the Central European Neolithic: Hungary to the Baltic. Antiquity 85, 43-58.

CZEKAJ-ZASTAWNY, A., KABACIŃSKI, J., TERBERGER, T. 2011b: Relacje łowiecko-zbierackich społeczności z Dąbek z kulturami neolitycznymi Europy środkowej. In: Stankiewicz, U., Wawrusiewicz, A. (Eds.): Na rubieży kultur. Badania nad okresem neolitu $i$ wczesna epoka brąu. Muzeum Podlaskie, Białystok, 161-174.

CZERNIAK, L. 1994: Wczesny i środkowy okres neolitu na Kujawach. 5400-3650 p.n.e. Instytut Archeologii i Etnologii PAN, Poznań.

CZERNIAK, L., DOMAŃSKA, L., KOŚKO, A., PRINKE, D. 1991: The Funnel Beaker culture in Kujavia. In: Jankowska, D. (Ed.): Die Trichterbecherkultur. Neue Forschungen und Hypothesen, Teil II., Instytut Prahistorii UAM \& Zakład Archeologii Wielkopolski IHKM, Poznań, 65-75.

CZERNIAK, L., PYZEL, J. 2011: Linear Pottery farmers and the introduction of pottery in the southern Baltic. Bericht der RömischGermanischen Kommission 89 (2008), 347-360.

DENNEL, R. 1985: The Hunter-Gatherer/Agricultural frontier in Prehistoric Temperate Europe. In: Green, S. W., Pearlman S. M. (Eds.): The Archaeology of Frontiers and Boundaries. Academic Press, San Diego, 113-139.

DOMAŃSKA, L. 2003: Hunter-gatherers and farmers: neighbours in northeastern Kuiavia, Poland. Documenta Praehistorica 30, 93-98.

FELCZAK, O. 2005: Wczesny i środkowy neolit na Pomorzu Gdańskim w świetle odkryć na Kociewiu. In: Fludziński, M., Paner, H. (Eds.), XIV Sesja Pomorzoznawcza, vol. 1: od epoki kamienia do okresu rzymskiego: 99-122. Muzeum Archeologiczne w Gdańsku, Gdańsk, 99-122.

GALIŃSKI, T. 2002. Społeczeństwa mezolityczne: osadnictwo, gospodarka, kultura ludów łowieckich w VIII-IV tysiacleciu p.n.e. na terenie Europy. Muzeum Narodowe w Szczecinie, Szczecin.

GEHLEN, B. 2006: Late Mesolithic - Proto-Neolithic - Initial Neolithic? Cultural and economic complexity in Southwestern Central Europe between 7000 and 5300 cal BC. In: Kind, C-J. (Ed.): After the Ice Age. Settlements, Subsistence and Social Development in the Mesolithic of Central Europe. Konrad Theiss, Stuttgart, 41-58.

GODŁOWSKA, M., KOZŁOWSKI, J. K., STARKEL L., WASYLIKOWA, K. 1987: Neolithic settlement at Pleszów and changes in the natural environment in the Vistula valley. Przeglad Archeologiczny 34, 133-159.

GRONENBORN, D. 1999: A variation on a basic theme: the transition to farming in southern Central Europe. Journal of World Prehistory 13, $123-210$.

GRONENBORN, D. 2007. Beyond the models: "Neolithisation" in Central Europe. In: Whittle, A., Cummings, V. (Eds.): Going Over: The Mesolithic-Neolithic Transition in North-West Europe. Oxford University Press; The British Academy, 73-98.

GRYGIEL, R. 2004: Neolit i początki epoki brazu $w$ rejonie Brześcia Kujawskiego i Ostonek, vol. I: Wczesnyneolit. Kultura ceramiki wstegowej rytej. Fundacja im. K. Jażdżewskiego \& Muzeum Archeologiczne i 
Etnograficzne w Łodzi, Łódź.

GUMIŃSKI, W. 1998: The peat-bog site Dudka, Masurian Lakeland: an example of conservative economy. In: Zvelebil, M., Domańska, L., Dennell, R. (Eds.): Harvesting the Sea, Farming the Forest: The Emergence of Neolithic Societies in the Baltic Region. Academic Press, Sheffield, 103-109.

GUMIŃSKI, W. 2003: Szczepanki 8. Nowe stanowisko torfowe kultury Zedmar na Mazurach. Światowit 5 (46), fasc. B, 53-104.

GUMIŃSKI, W. 2011: Importy i naśladownictwa ceramiki kultury brzeskokujawskiej i kultury pucharów lejkowatych na paraneolitycznym stanowisku kultury Zedmar - Szczepanki na Mazurach. In: Stankiewicz, U., Wawrusiewicz, A. (Eds.): Na rubieży kultur. Badania nad okresem neolitu i wczesna epoka brazu. Muzeum Podlaskie, Białystok, 149-160.

HARTZ, S., LÜBKE, H. 2005: Zur chronostratigraphischen Gliederung der Ertebølle-Kultur und frühesten Trichterbecherkultur in der südlichen Mecklenburger Bucht. Bodenkmalpflege in Mecklenburg-Vorpommern 52(2004): 119-144.

ILKIEWICZ, J. 2005: Wczesnoneolityczne narzędzia kamienne z Pobrzeża Koszalińskiego. Folia Praehistorica Posnaniensia 13/14, 91-116.

JANKOWSKA D., WIŚLAŃSKI T. 1991: Trichterbecherkultur im polnischen Tiefland. Die wichtigsten Forschungsprobleme. In: Jankowska, D. (Ed.): Die Trichterbecherkultur. Neue Forschungen und Hypothesen, Teil II, Instytut Prahistorii UAM \& Zakład Archeologii Wielkopolski IHKM, Poznań, 53-77.

JÓZWIAK, B. 2003: Spoleczności subneolitu wschodnioeuropejskiego na Niżu Polskim w międzyrzeczu Odry i Wisty. Uniwersytet Adama Mickiewicza, Poznań.

JÓZWIAK, B., DOMARADZKA, S. 2011: Studia nad osadnictwem społeczności subneolitycznych w Polsce północno-wschodniej. Zarys problematyki. In: Stankiewicz, U., Wawrusiewicz, A. (Eds.): Na rubieży kultur. Badania nad okresem neolitu i wczesna epoka brazu. Muzeum Podlaskie, Białystok, 87-102.

KABACIŃSKI, J. TERBERGER, T. 2009: From late hunter-fishers to early farmers on the Pomeranian coast. New research at Dąbki 9, Koszalin District. In: Burdukiewicz J., Cyrek, K., Dyczek, P., Szymczak, K. (Eds.): Understanding the Past. Papers offered to Stefan K. Kozłowski. University of Warsaw, Warsaw, 165-184.

KEMPISTY, E. 1983: Neolityczne kultury strefy leśnej w północnej Polsce. In: Malinowski, T. (Ed.): Problemy epoki kamienia na Pomorzu. Wyższa Szkoła Pedagogiczna w Słupsku, Słupsk, 175-199.

KLASSEN, L. 2004: Jade und Kupfer. Untersuchungen zum Neolithisierungsprozess im westlichen Ostseeraum unter besonderer Berücksichtigung der Kulturentwicklung Europas 5500-3500 BC. Jutland Archaeological Society, Moesgård.

KOŚKO, A. 1981: Udziat poludniowo-wschodnio-europejskich wzorców kulturowych $w$ rozwoju niżowych spoleczeństw kultury pucharów lejkowatych. Uniwersytet Adama Mickiewicza, Poznań.

KOZŁOWSKI, S. K. 1989: Mesolithic in Poland. A New Approach. Wydawnictwa Uniwersytetu Warszawskiego, Warszawa.

KUBIAK-MARTENS, L. 1999: The plant food component of the diet at the Late Mesolithic (Ertebølle) settlement at Tybrind Vig, Denmark. Vegetation History and Archaeobotany 8, 117-127.

KUBIAK-MARTENS, L. 2002: New evidence for the use of root foods in pre-agrarian subsistence recovered from the Late Mesolithic site at Halsskov, Denmark. Vegetation History and Archaeobotany 11, 23-32.

KUKAWKA, S. 1997: Na rubieży środkowoeuropejskiego świata rolniczego. Spoleczności Ziemi Chetmińskiej w IV tysiacleciu p.n.e. Uniwersytet Mikołaja Kopernika, Torun.

KUKAWKA, S. 2010: Subneolit pótnocno-wschodnioeuropejski na Niżu Polskim. Uniwersytet Mikołaja Kopernika, Torun.

KULCZYCKA-LECIEJEWICZOWA, A. 2000: Early Linear Pottery communities to the north of the Sudeten and Carpathian Mountains. Recent researches. Památky archeologické - Supplementum 13, 196-204.

KULCZYCKA-LECIEJEWICZOWA, A. 2010: The chronology of culture change among Linear Pottery communities north of the Carpathian Range. In: Šuteková, J., Pavúk, P., Kalábková P., Kovár B. (Eds.): Panta Rhei. Studies on the Chronology and Cultural Development of South-Eastern and Central Europe in Earlier Prehistory Presented to Juraj Pavúk on the Occasion of his $75^{\text {th }}$ Birthday. Comenius University in Bratislava \& Archaeological Centre in Olomouc, Bratislava, 549-560.
MAKOWIECKI, D. 2003: Historia ryb i rybolówstwa w holocenie na Niżu Polskim w świetle badań archeoichtiologicznych. Instytut Archeologii i Etnologii PAN, Poznań.

MATEICIUCOVÁ, I. 2008: Talking Stones: The Chipped Stone Industry in Lower Austria and Moravia and the Beginnings of the Neolithic in Central Europe (LBK), 5700-4900 BC. Masarykova univerzita, Brno.

NOWAK, M. 2001: The second phase of Neolithization in East-Central Europe. Antiquity 75, 582-592.

NOWAK, M. 2007: Middle and Late Holocene hunter-gatherers in East Central Europe: changing paradigms of the "non-Neolithic" way of life. Documenta Praehistorica 34, 89-103.

NOWAK, M. 2009: Drugi etap neolityzacji ziem polskich. Uniwersytet Jagielloński, Kraków.

O’SHEA, J.,ZVELEIBIL, M. 1984: Oleneostrovski mogilnik: reconstructing the social and economic organization of Prehistoric foragers in Northern Russia. Journal of Anthropological Archaeology 3, 1-40.

PELISIAK, A., RYBICKA, M., RALSKA-JASIEWICZOWA, M. 2006: From the Mesolithic to Modern Times: Settlement Organization and Economy Recorded in Annually Laminated Sediments of the Lake Gościaż (Central Poland). Fundacja Rzeszowskiego Ośrodka Archeologicznego; Instytut Archeologii Uniwersytetu Rzeszowskiego, Rzeszów.

PRICE, T. D., BROWN, J. A. (Eds.). 1985: Prehistoric Hunter-Gatherers. The Emergence of Cultural Complexity. Academic Press, Orlando.

RALSKA-JASIEWICZOWA, M. 2004. Late Holocene. In: RalskaJasiewiczowa, M. et al. (Eds.): Late Glacial and Holocene History of Vegetation in Poland Based on Isopollen Maps. W. Szafer Institute of Botany, Polish Academy of Sciences, Kraków: 405-410.

RALSKA-JASIEWICZOWA, M., VAN GEEL, B. 1998: Human impact on the vegetation of the Lake Gościąż surroundings in prehistoric and early-historic times. In: Ralska-Jasiewiczowa, M., Goslar, T., Madeyska, T., Starkel, L. (Eds.): Lake Gościąz, Central Poland: A Monographic Study, part 1. W. Szafer Institute of Botany, Polish Academy of Sciences, Kraków, 267-294.

RYBICKA, M. 2011: Przyczynek do badań nad datowaniem wczesnych faz kultury pucharów lejkowatych na Niżu Polski. Materiały i Sprawozdania Rzeszowskiego Ośrodka Archeologicznego 32, 231-238.

SCHILD, R. 1998: The perils of dating open-air sandy sites of the North European Plain. In: Zvelebil, M., Domańska, L., Dennell, R. (Eds.): Harvesting the Sea, Farming the Forest: The Emergence of Neolithic Societies in the Baltic Region. Sheffield Academic Press, Sheffield, $71-76$.

TERBERGER, T. 2006: The Mesolithic hunter-fisher-gatherers on the Northern German Plain. In: Hansen, K. M., Pedersen, K. B. (Eds.): Across the Western Baltic. Proceedings of the archaeological conference "The Prehistory and Early Medieval Period in the Western Baltic"

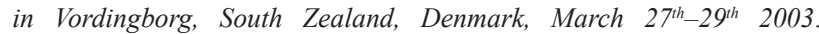
Sydsjællands Museum, 111-184.

THOMAS, J. 1999: Understanding the Neolithic. Routledge, London-New York.

VAN GIJN, A., ZVELEBIL, M. 1997: Stone age, ideology and scaling the ladder of inference. Analecta Praehistorica Leidensia 29: 3-12.

ZACHOWICZ, J., RALSKA-JASIEWICZOWA, M., MIOTKSZPIGANOWICZ, G., NALEPKA, D. 2004: Ulmus L. - Elm. In: RalskaJasiewiczowa, M. et al. (Eds.): Late Glacial and Holocene History of Vegetation in Poland Based on Isopollen Maps. W. Szafer Institute of Botany, Polish Academy of Sciences, Kraków, 225-235.

ZIMMERMANN, A., RICHTER, J., FRANK, T., WENDT, K. P. 2004: Landschaftsarchäologie II - Überlegungen zu Prinzipien einer Landschaftsarchäologie. Bericht der Römisch-Germanischen Kommission 85, 37-94.

ZVELEBIL, M. 1981: From Forager to Farmer in the Boreal Zone. Reconstructing Economic Patterns Through Catchment Analysis in Prehistoric Finland. BAR Int. Series 115, Oxford.

ZVELEBIL, M. 1986a: Mesolithic prelude and neolithic revolution. In: Zvelebil, M. (Ed.): Hunters in Transition. Mesolithic Societies of Temperate Eurasia and Their Transition to Farming. Cambridge University Press, Cambridge, 5-15.

ZVELEBIL, M. 1986b: Mesolithic societies and the transition to farming: problems of time, scale and organization. In: Zvelebil, M. (Ed.): Hunters in Transition. Mesolithic Societies of Temperate Eurasia and Their Transition to Farming. Cambridge University Press, Cambridge, 167-188. 
ZVELEBIL, M. 1989: Economic intensification and postglacial huntergatherers in North Temperate Europe. In: Bonsall, C. (Ed.): The Mesolithic in Europe. Papers Presented at the Third International Symposium, Edinburgh 1985. John Donald, Edinburgh, 81-90.

ZVELEBIL, M. 1994: Plant use in the Mesolithic and its role in the transition to farming. Proceedings of the Prehistoric Society 60, 35-74.

ZVELEBIL, M. 1995a: Hunting, gathering, or husbandry? Management of food resources by the Late Mesolithic communities of Temperate Europe. In: Campana, D. V. (Ed.): Before Farming: Hunter-Gatherer Society and Subsistence. University of Pennsylvania Museum of Archaeology and Anthropology, Philadelphia, 79-104.

ZVELEBIL, M. 1995b: Indo-European origins and the agricultural transitions in Europe. In: Kuna, M., Venclová, N. (Eds.): Whither Archaeology? Papers in Honour of Evžen Neustupný. Institute of Archaeology, Academy of Sciences of the Czech Republic, Praha, 173-203.

ZVELEBIL, M. 1996a: Subsistence and social organization of the Mesolithic communities in Temperate and Northern Europe. In: Tozzi, C. (Ed.), The Colloquia of the XIII International Congress of Prehistoric and Protohistoric Sciences, vol. 7, The Mesolithic. A.B.A.C.O., Forli, 59-78.

ZVELEBIL, M. 1996b: The agricultural frontier and the transition to farming in the circum-Baltic region. In: Harris D. (Ed.): The Origins and Spread of Agriculture and Pastoralism in Eurasia. University College of London Press, London, 323-345.

ZVELEBIL, M. 1997: Hunter-gatherer ritual landscapes: spatial organisation, social structure and ideology among hunter-gatherers of northern Europe and western Siberia. Analecta Praehistorica Leidensia 29, 18-50.

ZVELEBIL, M. 1998: Agricultural frontiers, Neolithic origins, and the transition to farming in the Baltic Basin. Zvelebil, M., Domańska, L., Dennell, R. (Eds.): Harvesting the Sea, Framing the Forest: The Emergence of Neolithic Societies in the Baltic Region. Sheffield Academic Press, Sheffileld, 9-28.

ZVELEBIL, M. 2001: The agricultural transition and the origins of Neolithic society in Europe. Documenta Praehistorica 28, 1-27.

ZVELEBIL, M. 2002: Demography and dispersal of early farming populations at the Mesolithic-Neolithic transition: linguistic and genetic implications. In: Bellwood, P., Renfrew, C. (Eds.): Examining the farming/ language dispersal hypothesis. McDonald Institute for Archaeological Research, Cambridge, 379-394.
ZVELEBIL, M. 2003a: People behind the lithics. Social life and social conditions of Mesolithic communities in temperate Europe. In: Bevan, L., Moore, J. (Eds.), Peopling the Mesolithic in a Northern Environment. BAR Int. Series 1157, Archaeopress, Oxford, 1-30.

ZVELEBIL, M. 2003b: Enculturation of Mesolithic landscapes. In: Larsson, L. et al. (Eds.): Mesolithic on the Move. Papers Presented at the Sixth International Conference on the Mesolithic in Europe, Stockholm 2000. Oxbow, Oxford, 65-73.

ZVELEBIL, M. 2003c: The Mesolithic of Eastern Europe. In: Bogucki, P., Crabtree P. (Eds.): Ancient Europe 8000 B.C. to A.D. 1000. Encyclopedia of the Barbarian World. Scribners \& Sons, 183-192.

ZVELEBIL, M. 2004a: Who were we 6000 years ago? In search of prehistoric identities. In: Jones, M. (Ed.), Traces of Ancestry: Studies in Honour of Colin Renfrew. McDonald Institute for Archaeological Research, Cambridge, 41-60.

ZVELEBIL, M. 2004b: Conclusion: The many origins of the LBK. In: Lukes, A., Zvelebil, M. (Eds.): LBK Dialogues. Studies in the Formation of the Linear Pottery Culture. BAR Int. Series 1304, Archaeopress, Oxford, 183-205.

ZVELEBIL, M. 2005: Homo habitus: agency, structure and the transformation of tradition in the constitution of the TRB foragingfarming communities in the North European plain (ca 4500-2000 BC). Documenta Praehistorica 32, 87-103.

ZVELEBIL, M. 2006: Mobility, contact, and exchange in the Baltic Sea basin 6000-2000 BC. Journal of Anthropological Archaeology 25, 178192.

ZVELEBIL, M., DOLUKHANOV, P. 1991: The transition to farming in Eastern and Northern Europe. Journal of World Prehistory 5, 233-278.

ZVELEBIL, M., JORDAN, P. 1999: Hunter fisher gatherer ritual landscapes - questions of time, space and representation. In: Goldham, J. (Ed.): Rock Art as Social Representation. BAR Int. Series 794, Archaeopress, Oxford, 101-127.

ZVELEBIL, M., LILLIE, M. 2000: Transition to agriculture in eastern Europe, In: Price, T. D. (Ed.): Europe's First Farmers. Cambridge University Press, 57-93.

ZVELEBIL, M., ROWLEY-CONWY, P. 1984: Transition to farming in Northern Europe: a hunter-gatherer perspective. Norwegian Archaeological Review 17, 104-128.

ZVELEBIL, M., ROWLEY-CONWY, P. 1986: Foragers and farmers in Atlantic Europe. In: Zvelebil, M. (Ed.): Hunters in Transition. Mesolithic Societies of Temperate Eurasia and Their Transition to Farming. Cambridge University Press, Cambridge, 67-93. 